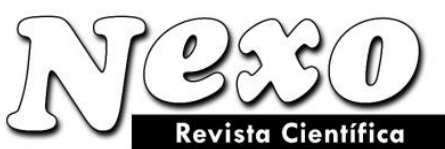

Vol. 33, No. 02, pp. 286-296/Diciembre 2020

\title{
Study of the petrography and tectonic settings of sills in Lavasanat district, Tehran (north of Iran)
}

\section{Estudio de la petrografía y la configuración tectónica de los umbrales en el distrito de Lavasanat, Teherán (norte de Irán)}

\author{
Mehdi Bina ${ }^{1}$, Mohammad Ali Arian*1 ${ }^{* 1}$ Mohsen Pourkermani ${ }^{1}$, Mohammad Hasan Bazoobandi ${ }^{2}$, Abdollah \\ Yazdi $^{3}$ \\ ${ }^{1}$ Department of Geology, Faculty of Sciences, North Tehran Branch, Islamic Azad University, \\ Tehran, Iran. \\ ${ }^{2}$ Faculty of Science, University of Farhangian, Tehran, Iran. \\ ${ }^{3}$ Department of Geology, Kahnooj Branch, Islamic Azad University, Kahnooj, Iran.
}

Corresponding author Email: maa1361@yahoo.com

(recibido/received: 10-May-2020; aceptado/accepted: 18-June-2020)

\begin{abstract}
The study area is located in Lavasanat District in the northeast of Tehran in Central Alborz zone. The outcrops are mainly linked to Karaj Formation, which belongs to the upper Eocene to Oligocene periods. In the study area, there are various plutonic rocks that are identified in the form of numerous dike and sill on the ground. These sills are injected in between sedimentary layers. The rocks forming the sills include the spectrum of gabbro, gabbro diorite, diorite, monzonite, and syenite. In some areas, these rocks have undergone alterations and have traces of the saussuritization and chloritization phenomena. There are also two generations of amorphous. The first generation is fully chloritized due to alteration while the second generation is unaltered. Unlike many diorites and monzonites, which typically have hornblendes, the neutral rocks such as diorite and monzonite lack hornblendes. Hence, their magmas were dry and dehydrated. Based on the geochemical studies conducted on 17 samples (15 sill samples and 2 host rock samples) and the diagrams of the tectonic settings of rocks, the study sills are in the WIN (within plate). However, two samples of the host rock are within the range of the active continental margins.
\end{abstract}

Keywords: sill, tectonic setting, petrography, Lavasanat, Tectonic Setting of Sills

\section{RESUMEN}

El área de estudio se encuentra en el distrito de Lavasanat, en el noreste de Teherán, en la zona central de Alborz. Los afloramientos están principalmente vinculados a la Formación Karaj, que pertenece a los períodos del Eoceno superior al Oligoceno. En el área de estudio, hay varias rocas plutónicas que se 
identifican en forma de numerosos diques y antepechos en el suelo. Estos umbrales se inyectan entre capas sedimentarias. Las rocas que forman los umbrales incluyen el espectro de gabro, gabro diorita, diorita, monzonita y sienita. En algunas áreas, estas rocas han sufrido alteraciones y tienen rastros de los fenómenos de saussuritización y cloritización. También hay dos generaciones de amorfos. La primera generación está completamente cloritizada debido a la alteración, mientras que la segunda generación no se altera. A diferencia de muchas dioritas y monzonitas, que típicamente tienen hornblendes, las rocas neutras como la diorita y la monzonita carecen de hornblendes. Por lo tanto, sus magmas estaban secos y deshidratados. Según los estudios geoquímicos realizados en 17 muestras (15 muestras de alféizar y 2 muestras de roca huésped) y los diagramas de los ajustes tectónicos de las rocas, los alféizares del estudio están en el WIN (dentro de la placa). Sin embargo, dos muestras de la roca huésped están dentro del rango de los márgenes continentales activos.

Palabras clave: Umbral, configuración tectónica, petrografía, Lavasanat, configuración tectónica de umbrales

\section{INTRODUCTION}

Alborz Mountain Range, which is in the north of Iran with a length of approximately $900 \mathrm{~km}$ and a width of approximately $100 \mathrm{~km}$, shows an active deformation in the southern bank of the Caspian Sea. This mountain range is an extension of the active Alpine-Himalayan orogenic belt in West Asia and its active deformation is caused by the convergence and the collision between the Arabian Plate and Eurasia. The study region has a surface area of $337 \mathrm{~km}$ and it is located at a distance of approximately $10 \mathrm{~km}$ from the east of Tehran in the north of Jajroud. This area is situated between the longitude of $355^{\prime} 51^{\circ}-50 ' 51^{\circ} \mathrm{E}$ and the latitude of $35^{\prime} 45^{\circ}-35^{\prime} 53^{\circ} \mathrm{N}$ (Fig. 1).

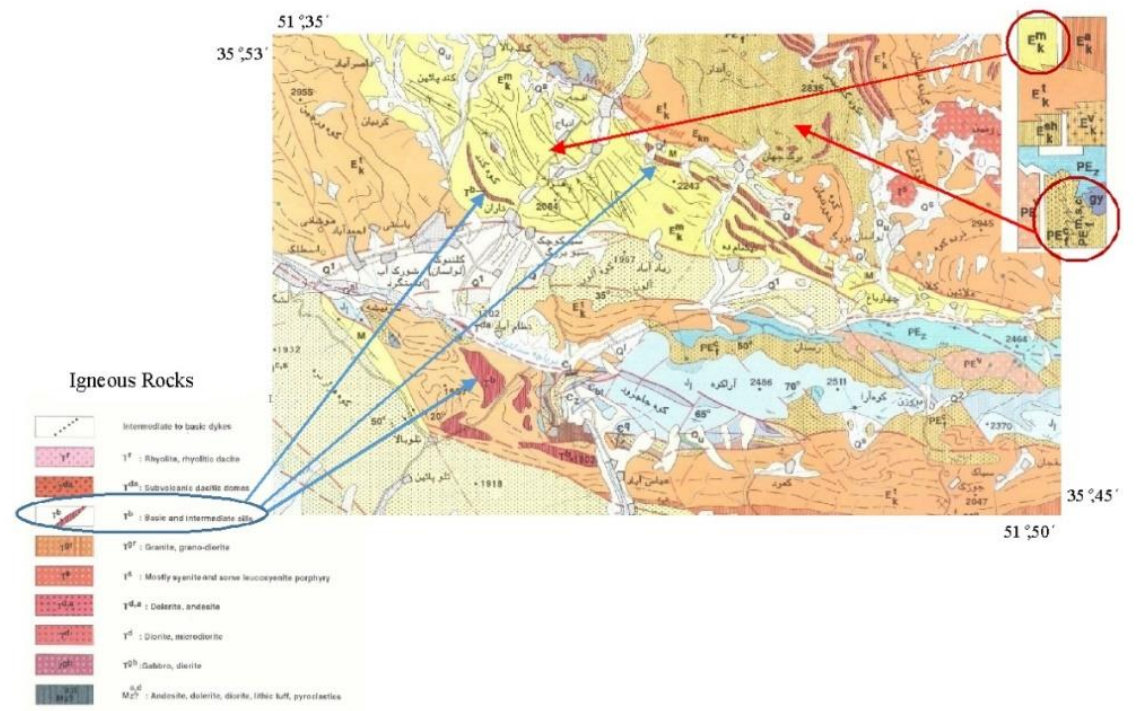

Figure (1): The geological setting of the study area, Vahdati Daneshmand, F. (1995)

The study area is a part of the Central Alborz zone, and the Karaj Formation has the highest number of outcrops. It consists of two intrusions: one in the north and one in the northeast of Lavasan. There is a juxtaposition of various rock units with different ages in the study area. The Eocene rocks are present in the form of folds and younger units are locally placed on top of them. 
The intrusions in Lavasanat region are generally a combination of a spectrum of gabbro to syenite and neutral rocks and they are placed in between the sediments. These intrusions are observed in the sill and dike forms. We study the sill intrusions in the study area.

\section{RESEARCH METHOD}

Data gathering, using scientific-research local and foreign articles, reading theses and reports on the study area in the university libraries, the Geological Survey and Mineral Exploration of Iran, and Internet sources.

Using different information layers such as the 1:100000 quadrangle geological maps of the east of Tehran, topographic maps, aerial photos, and satellite images of the study area for selecting the regular survey routes in the field operations.

Conducting field inspections and proper marking of lithological diversities using GPS, properly collecting samples from healthy and less altered outcrops in the region for petrography, mineral chemistry, and rock geochemistry.

Conducting petrographic studies on more than 100 sections obtained from minerals isolated using polarized light microscopes.

Performing geochemical analyses on 17 samples.

Creating diagrams of the tectonic settings of rocks using geochemical data.

Concluding data obtained from field and experimental works.

\section{PETROGRAPHY}

The petrographic analysis of rocks in the study area reveals the existence of different plutonic rocks. Most samples lack quartz minerals and are highly similar from the mineralogical and lithological viewpoints. For example, they contain similar minerals according to petrographic studies.

All of these samples are composed of several plagioclase group minerals, which include orthoclase, olivine, and opaque minerals. In some samples, aegirine augite and biotite are also identified.

Based on the classification, the rocks in the study area (Streekeisen 1974-1980) include gabbro, gabbro diorite, diorite, monzonite, and syenite (Fig. 1).

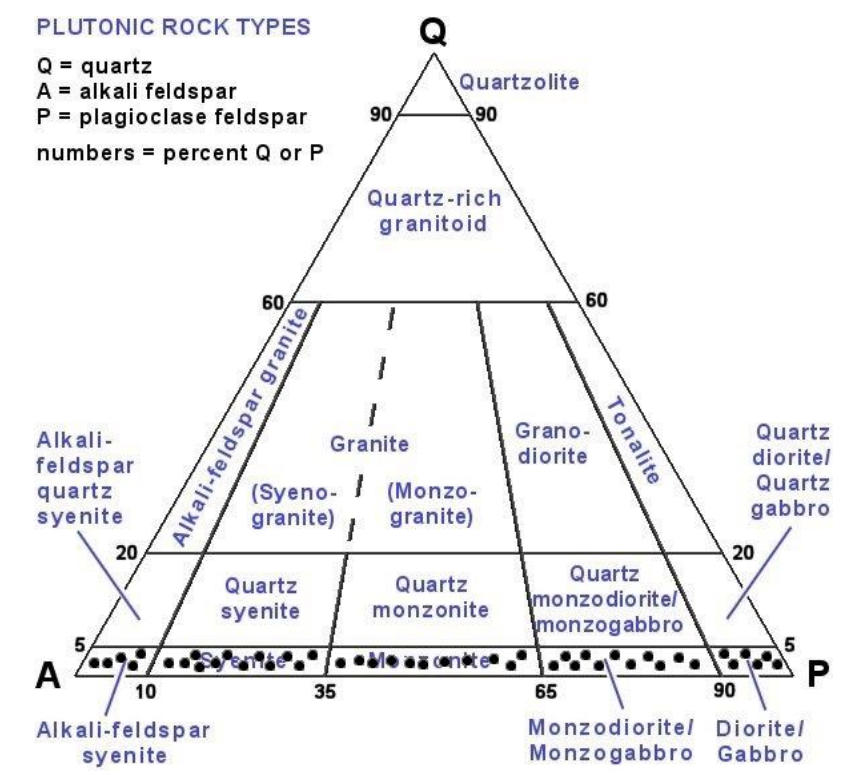

Diagram (1): The settings of the study rocks on Streekeisen diagram 


\subsection{Gabbro}

Gabbro sills are present in the study area in colors black and greenish black. The collected samples have granular texture, intergranular texture, or both of them. The primary minerals include plagioclase (labradorite) and pyroxene (augite). Opaque minerals are also present in the form of secondary minerals in gabbros. The secondary minerals include chlorite, sericite, and epidote, which resulted from saussuritization of plagioclases. The alteration of augites also led to the formation of uralite minerals. Chloritization of pyroxenes and saussuritization of plagioclases are the result of the alteration of these rocks. There are two generations of amorphous pyroxenes: the first generation is fully chloritized due to alteration while the second generation is unaltered (Fig. 1).

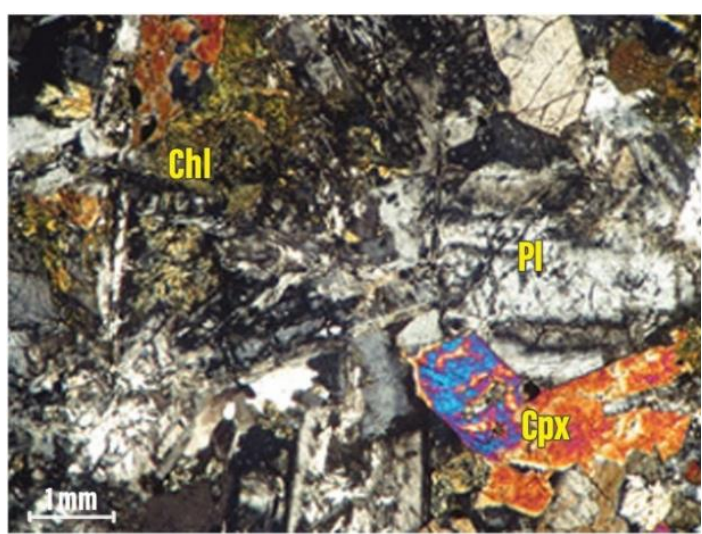

Figure (1): The microscopic image of a gabbro under crossed polarized light(XPL)

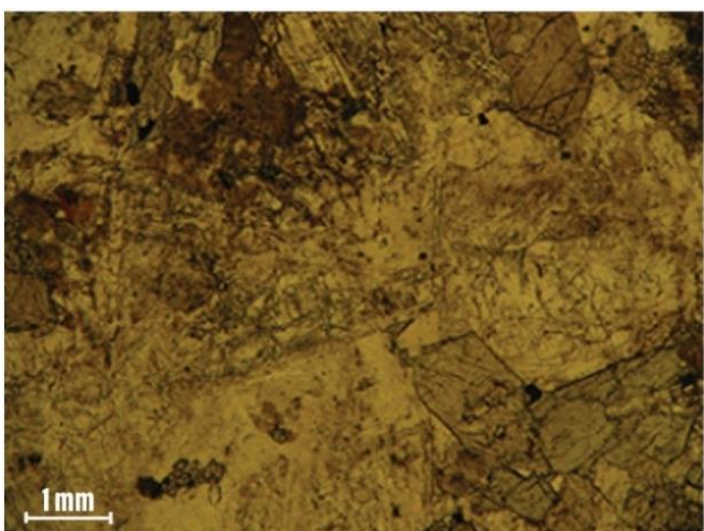

Figure (2): The microscopic image of a gabbro under plane polarized light (PPL)

\subsection{Gabbro Diorite}

Some of the study sills are in the range between gabbros and diorites with regard to their lithology. Therefore, the name gabbro or diorite cannot be really used for them and they also contain approximately $52 \%$ silicon according to chemical analyses, which complies with the microscopic diagnoses. The primary minerals include plagioclase (including andesine-labradorite) and pyroxene (augite). According to the analyses conducted using a polarized light microscope, the feldspars are plagioclases. Augites are present in colors black and greenish black. Moreover, two perpendicular cleavages in the cross-sections and a series of good cleavages in the longitudinal sections with vitreous luster are identified. The angle of extinction of plagioclases, which is measured using the Michelle Levy method, is 27.5 degrees, and the anorthite level is 50\%, which represents the andesine-labradorite mixture.

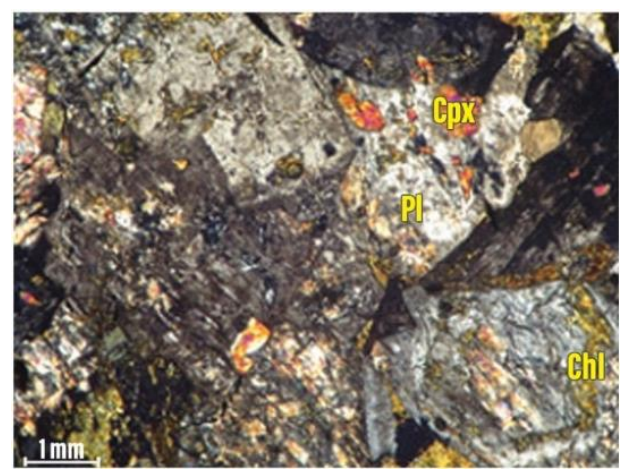

Figure (3): The microscopic image of a gabbro diorite under crossed polarized light(XPL)

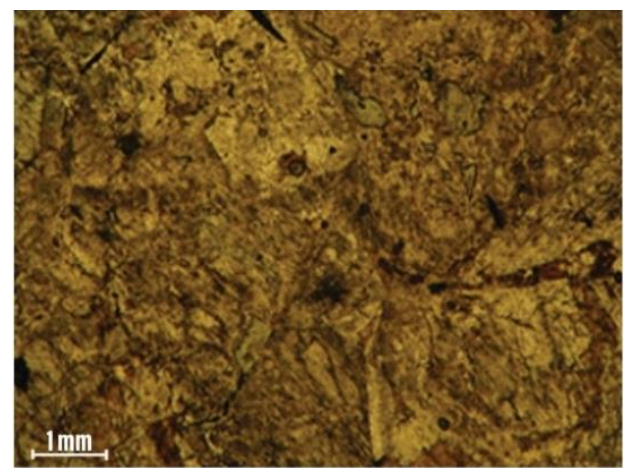

Figure (2): The microscopic image of a gabbro diorite under plane polarized light (PPL) 


\subsection{Diorite}

Diorites in the study area have low spread and small outcrops. Unlike many diorites that often have hornblendes, they lack any hornblende, which shows the dehydration and lack of moisture in their magmas. Most samples have medium-grained textures and fewer diorite sills have intergranular textures. Plagioclase and pyroxene of the augite group are the primary minerals of the diorites. The secondary minerals include opaque minerals and aegirine augites. Chlorite minerals with a light green color are among the products of the alteration of plagioclases. There are very fine epidotes on the body of plagioclases, which are the product of saussuritization of plagioclases.

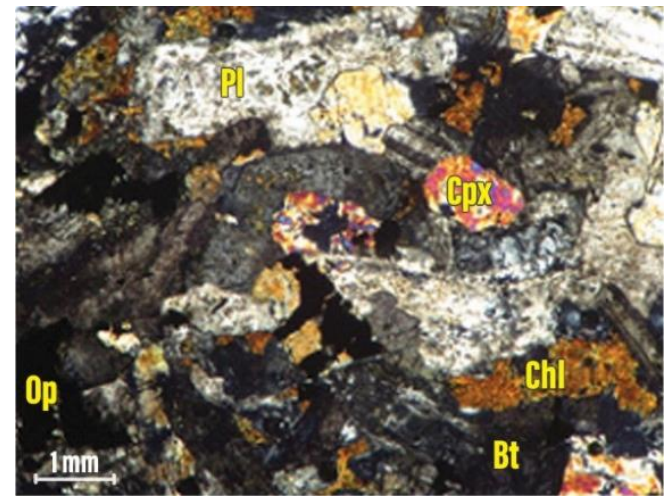

Figure (5): The microscopic image of a diorite under crossed polarized light (XPL)

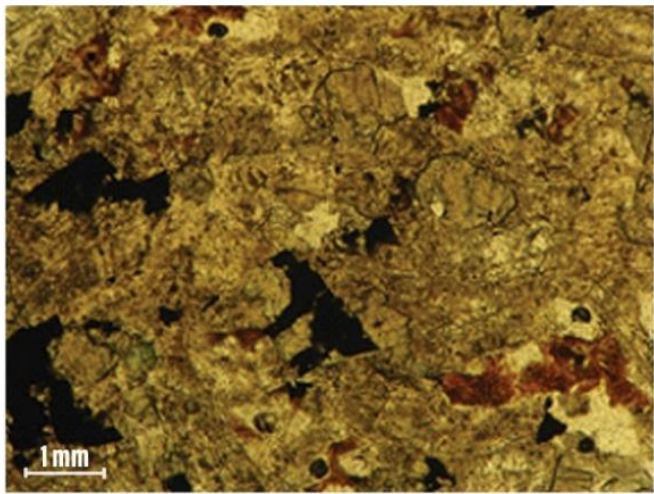

Figure (6): The microscopic image of a diorite under plane polarized light (PPL)

\subsection{Monzonite}

Monzonites have low spread and small outcrops. Unlike many monzonites, which typically have hornblendes, these monzonites lack any hornblende. This indicates the dehydration and low moisture of their constituting magma. Most samples have medium-grained textures. Alkali feldspars of the oligoclase type are observed in this rock. Fine chlorite and epidote crystals are the products of the alteration of plagioclases. Besides, pyroxenes are of the augite type and augites have a frequency of 10 to $33 \%$.

Opaque minerals with a frequency of 8 to $15 \%$ form the secondary minerals. The secondary minerals include zeolites of the natrolite type, which are identified as gramineous zeolites with a maximum size of $2 \mathrm{~mm}$ and a frequency of 3 to $11 \%$. Chlorites are also available with a frequency of 4 to $7 \%$.

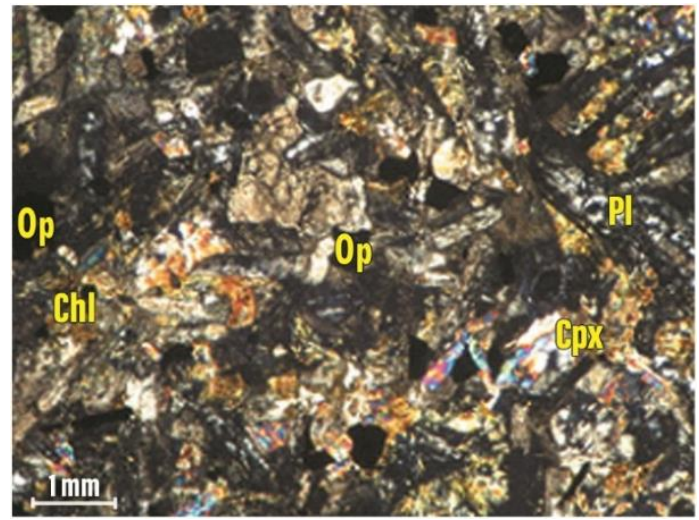

Figure (7): The microscopic image of a monzonite under crossed polarized light(XPL)

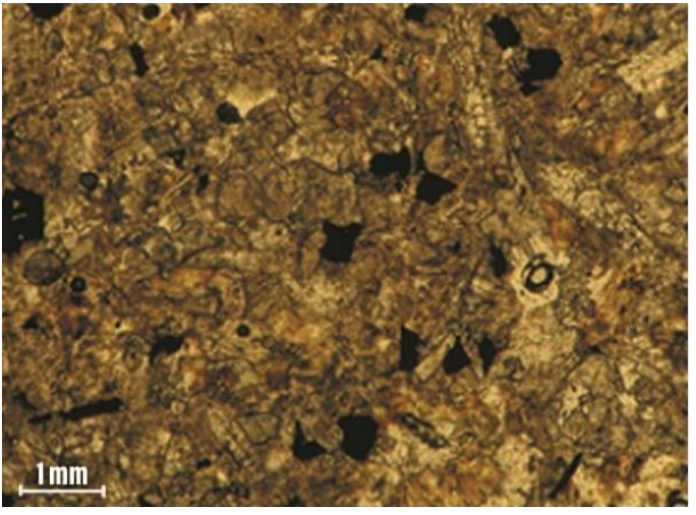

Figure (8): The microscopic image of a monzonite under plane polarized light (PPL) 


\subsection{Syenite}

Syenites are fully crystalline and medium-grained. The feldspars have a good cleavage and vitreous luster and are considered the most abundant minerals. Therefore, orthoclase and albite are the primary minerals of the rock. Orthoclases have three series of cleavages and are colorless under PPL light. They have clear cleavages and weak negative extrusions. They also have a mild angle of extinction and very beautiful Carlsbad macles. The plagioclases in these syenites are fully albite. They have many polysynthetic macles under PPL light. Biotite and opaque minerals are considered the secondary minerals of syenites (Fig. 9).

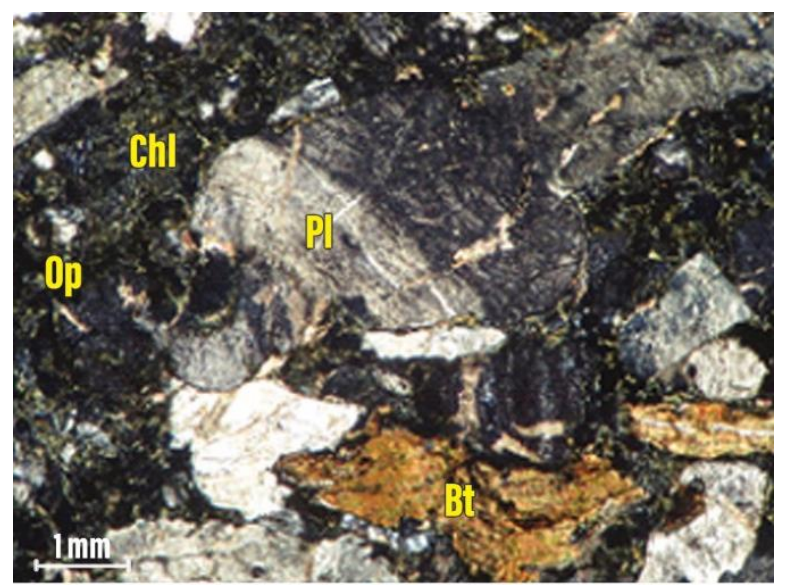

Figure (9): The microscopic image of a syenite under crossed polarized light(XPL)

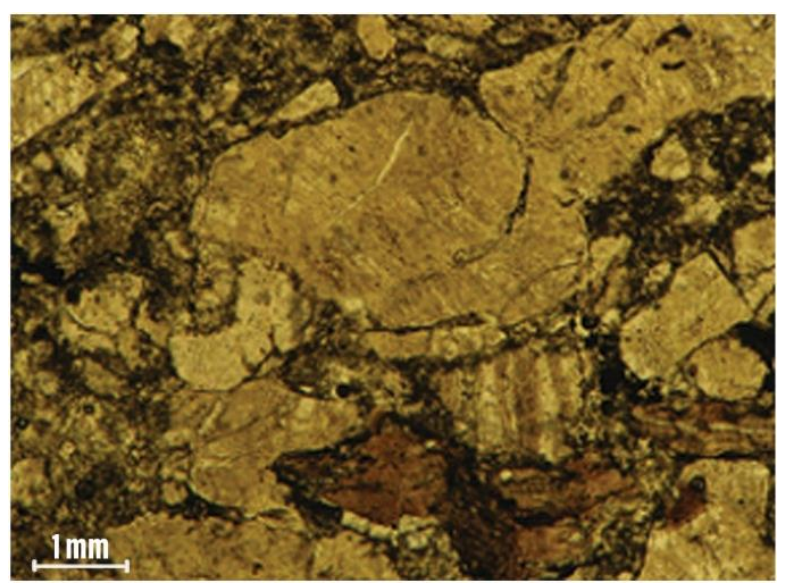

Figure (10): The microscopic image of a syenite under plane polarized light (PPL)

Calcite and sericite minerals are present in the form of secondary minerals in syenites. A small number of sericites is produced by the alteration of the albite and orthoclase feldspars. Calcite, as the secondary mineral, along with opaque minerals, fills the pores and seams of the rocks (Fig. 11).

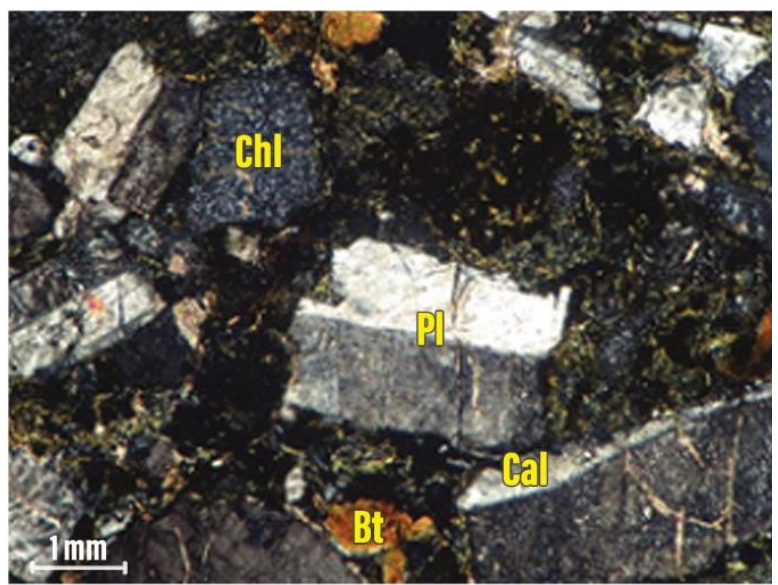

Figure (11): The microscopic image of a syenite under crossed polarized light(XPL)

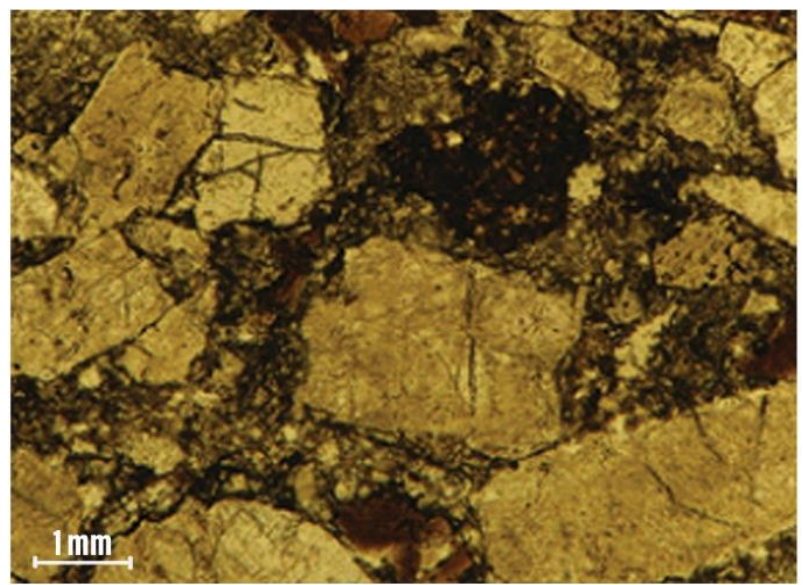

Figure (12): The microscopic image of a syenite under plane polarized light (PPL)

\section{Tectonic Setting of Sills}

Sills with different mechanisms form in different tectonic settings. One of the common and reliable methods of determining the tectonic settings of sills is using geochemical data and related diagrams. In this chapter, geochemical data and the following diagrams are used to attain this goal. 
Table (1): The analysis of the primary elements collected from the region

\begin{tabular}{|c|c|c|c|c|c|c|c|c|c|c|c|c|c|c|c|c|c|}
\hline Sample & $\mathrm{SiO}_{2}$ & $\mathrm{Al}_{2} \mathrm{O}_{3}$ & $\mathrm{BaO}$ & $\mathrm{CaO}$ & $\mathrm{Fe}_{2} \mathrm{O}_{3}$ & $\mathrm{~K}_{2} \mathrm{O}$ & $\mathrm{MgO}$ & $\mathrm{MnO}$ & $\mathrm{Na}_{2} \mathrm{O}$ & $\mathrm{P}_{2} \mathrm{O}_{5}$ & $\mathrm{SO}_{3}$ & $\mathrm{TiO}_{2}$ & $\mathrm{Cr}_{2} \mathrm{O}_{3}$ & LoI & $\mathrm{Cu}$ & $\mathrm{Sr}$ & $\mathrm{Zr}$ \\
\hline S-8 & $48 / 58$ & $15 / 62$ & $<$ & $8 / 5$ & $9 / 64$ & $1 / 36$ & $4 / 88$ & $0 / 17$ & $4 / 54$ & $0 / 49$ & $0 / 05$ & $2 / 23$ & $<$ & $3 / 88$ & $<$ & $0 / 08$ & $<$ \\
\hline S-10 & $45 / 96$ & $14 / 81$ & $<$ & $6 / 65$ & $9 / 69$ & $1 / 14$ & $7 / 88$ & $0 / 17$ & $4 / 81$ & $0 / 38$ & $<$ & $1 / 97$ & $0 / 05$ & $6 / 5$ & $<$ & $<$ & $<$ \\
\hline S-27 & $44 / 01$ & $15 / 45$ & $<$ & $5 / 61$ & 9/92 & $1 / 41$ & $4 / 7$ & $0 / 15$ & $4 / 39$ & $0 / 57$ & $0 / 06$ & $2 / 77$ & $<$ & $10 / 96$ & $<$ & $<$ & $<$ \\
\hline S-52 & $44 / 33$ & $16 / 02$ & $<$ & $7 / 45$ & $10 / 66$ & $3 / 45$ & $4 / 44$ & $0 / 17$ & $3 / 11$ & $0 / 58$ & $0 / 09$ & $3 / 07$ & $<$ & $6 / 41$ & $<$ & $0 / 23$ & $<$ \\
\hline S-60 & $46 / 64$ & $15 / 89$ & $<$ & $8 / 06$ & $8 / 22$ & $1 / 19$ & $5 / 02$ & $0 / 27$ & $5 / 75$ & $0 / 54$ & $<$ & $2 / 16$ & $<$ & $5 / 52$ & $0 / 74$ & $<$ & $<$ \\
\hline S-62 & 57 & $15 / 4$ & $<$ & $5 / 31$ & $5 / 99$ & $4 / 57$ & 2 & $0 / 1$ & $5 / 37$ & $0 / 25$ & $<$ & $1 / 36$ & $<$ & $2 / 59$ & $<$ & $<$ & $0 / 08$ \\
\hline S-63 & $48 / 47$ & $15 / 75$ & $<$ & $8 / 67$ & $9 / 6$ & $1 / 17$ & $5 / 9$ & $0 / 16$ & 4 & $0 / 34$ & $0 / 09$ & $1 / 97$ & $<$ & $3 / 86$ & $<$ & $0 / 06$ & $<$ \\
\hline S-65 & $48 / 42$ & $15 / 6$ & $<$ & $8 / 04$ & $9 / 7$ & $1 / 32$ & $6 / 65$ & $0 / 15$ & $3 / 82$ & $0 / 33$ & $0 / 13$ & $2 / 02$ & $<$ & $3 / 82$ & $<$ & $<$ & $<$ \\
\hline S-68 & $50 / 17$ & $14 / 35$ & $<$ & $6 / 25$ & $10 / 1$ & $1 / 06$ & $6 / 27$ & $0 / 31$ & $4 / 79$ & $0 / 44$ & $0 / 28$ & $2 / 14$ & $<$ & $3 / 85$ & $<$ & $<$ & $<$ \\
\hline S-71 & 50 & $14 / 58$ & $<$ & 7 & $8 / 5$ & $1 / 02$ & $5 / 32$ & $0 / 13$ & $5 / 81$ & $0 / 43$ & $0 / 11$ & $2 / 18$ & $<$ & $4 / 9$ & $<$ & $<$ & $<$ \\
\hline S-90 & $47 / 94$ & $15 / 95$ & $<$ & $7 / 62$ & $9 / 31$ & $1 / 16$ & $4 / 54$ & $0 / 14$ & $5 / 55$ & $0 / 32$ & $0 / 17$ & $2 / 12$ & $<$ & $5 / 09$ & $<$ & $0 / 08$ & $<$ \\
\hline S-80 & $48 / 75$ & $15 / 67$ & $<$ & $7 / 51$ & $9 / 51$ & $1 / 49$ & $5 / 49$ & $0 / 15$ & $4 / 47$ & $0 / 32$ & $<$ & $2 / 12$ & $<$ & $4 / 41$ & $<$ & $0 / 1$ & $<$ \\
\hline S-83 & $48 / 58$ & $15 / 12$ & $<$ & $6 / 77$ & $10 / 78$ & $1 / 61$ & $4 / 64$ & $0 / 18$ & $5 / 14$ & $0 / 49$ & $<$ & $2 / 72$ & $<$ & $3 / 9$ & $<$ & $0 / 06$ & $<$ \\
\hline S-84 & $51 / 02$ & $14 / 58$ & $0 / 05$ & $5 / 49$ & $11 / 16$ & $2 / 37$ & $3 / 28$ & $0 / 2$ & $5 / 55$ & $0 / 59$ & $<$ & $2 / 79$ & $<$ & $2 / 93$ & $<$ & $<$ & $<$ \\
\hline S-86 & $48 / 93$ & $15 / 79$ & $0 / 07$ & $6 / 78$ & $9 / 82$ & $1 / 68$ & $5 / 14$ & $0 / 17$ & $4 / 95$ & $0 / 42$ & $<$ & $2 / 1$ & $<$ & $4 / 04$ & $<$ & $0 / 11$ & $<$ \\
\hline S-94 & $51 / 85$ & $17 / 1$ & $0 / 09$ & $4 / 69$ & $8 / 22$ & $4 / 31$ & $3 / 13$ & $0 / 25$ & $3 / 62$ & $0 / 34$ & $0 / 2$ & $1 / 12$ & $<$ & 5 & $<$ & $0 / 08$ & $<$ \\
\hline S-95 & $52 / 87$ & $17 / 61$ & $0 / 1$ & $4 / 5$ & $6 / 63$ & $4 / 56$ & $2 / 83$ & $0 / 22$ & $3 / 78$ & $0 / 29$ & $0 / 12$ & $0 / 97$ & $<$ & $5 / 43$ & $<$ & $0 / 08$ & $<$ \\
\hline
\end{tabular}

\subsection{TiO2-Al2O3 Diagram (Muller \& Groves, 1997)}

In this diagram, different types of rocks belonging to island arcs are distinguished from the within plate rocks. According to the diagram (Fig. 13), all the samples of the study area except for samples S94, S95, and S62, which represent the host rock, are in the within plate (WIP) range.

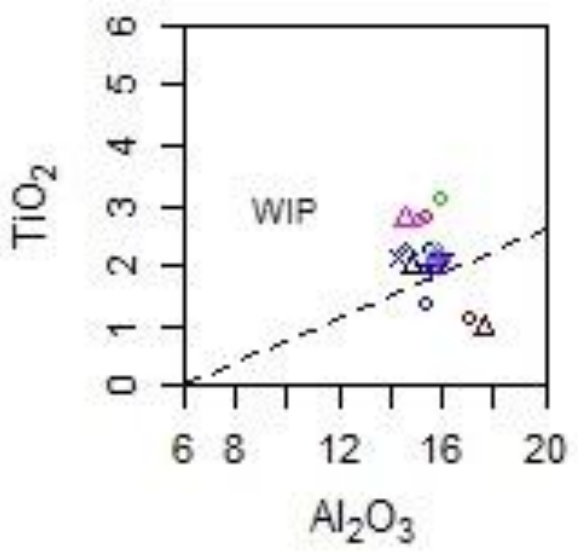

Figure (13): The diagram of the tectonic settings of rocks in the study area

\subsection{TiO2 versus K2O Diagram (Trop, 1987)}

In this diagram, the rocks in the subduction zone are distinguished from the rocks in the intercontinental rift. Based on this diagram (Fig. 14), all the samples collected from the sills in the study area are in the within plate (WIP) zone and the samples of the host rock are on the boundary of the subduction zone. 


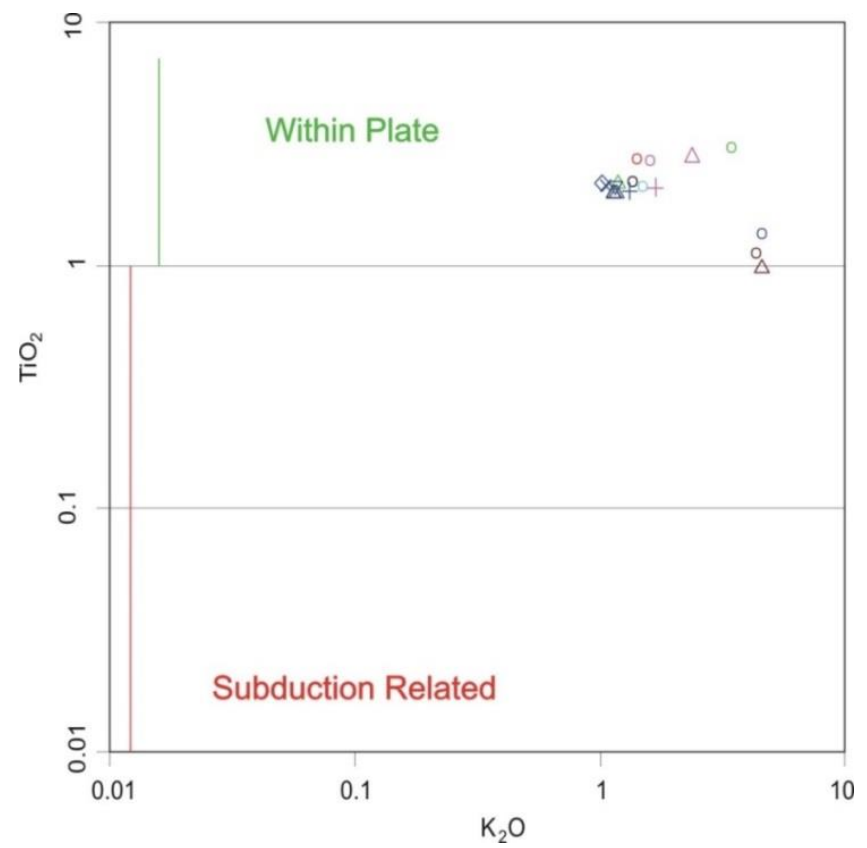

Figure (14): The diagram of the tectonic settings of sills and host rocks (Trop, 1987)

\subsection{Zr-Ti Diagram (Pearce, 1982)}

Pearce proposed the $\mathrm{Zr}$ - $\mathrm{Ti}$ logarithmic graph to differentiate between the basic rocks in the mid-ocean and within plate ridges and island arcs. As seen in the diagram, all the sill samples in the region are in the within plate range (Fig. 15). Samples S94 and S95 of the host rock are within the range of environments associated with the continental arc.

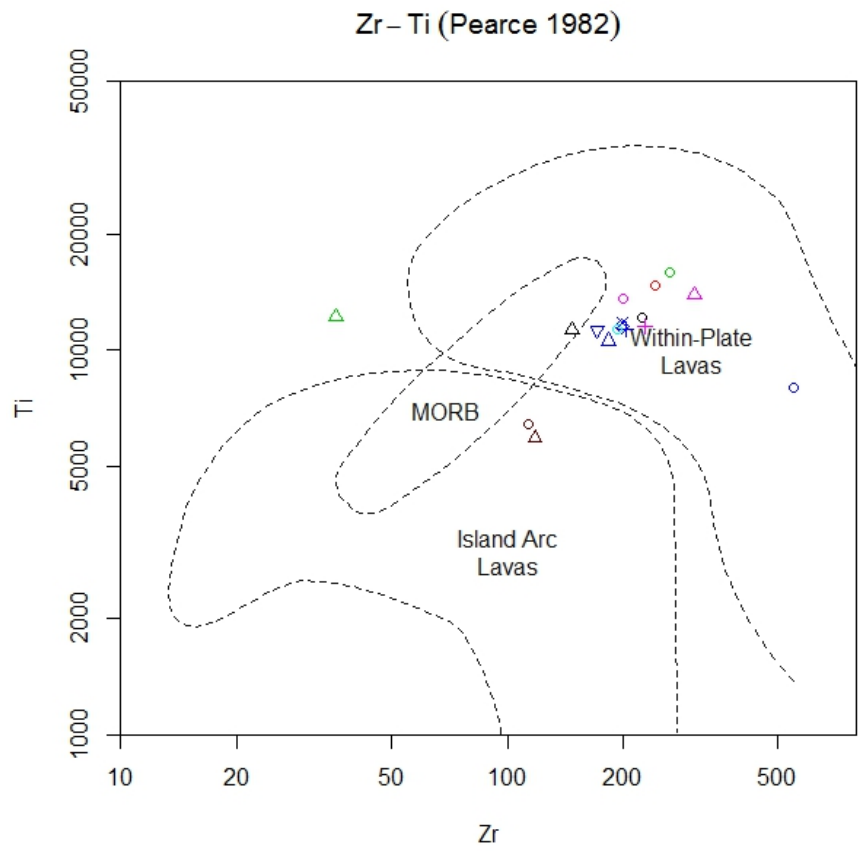

Figure (15): The tectonic setting of the rocks in the study area for the separation of island arcs, mid-ocean basalt, and within plate basalts (Pearce, 1982) 


\subsection{Hf-Rb/30-3Ta Ternary Diagram (Harris et al., 1986)}

In this diagram, which is used to differentiate between the intracontinental zones, the sills in the study area are in the within plate range and the host rock sample is in Group3 (Fig. 16).

\section{$\mathrm{Hf}-\mathrm{Rb} / 30-3 \mathrm{Ta}$ (Harris et al. 1986)}

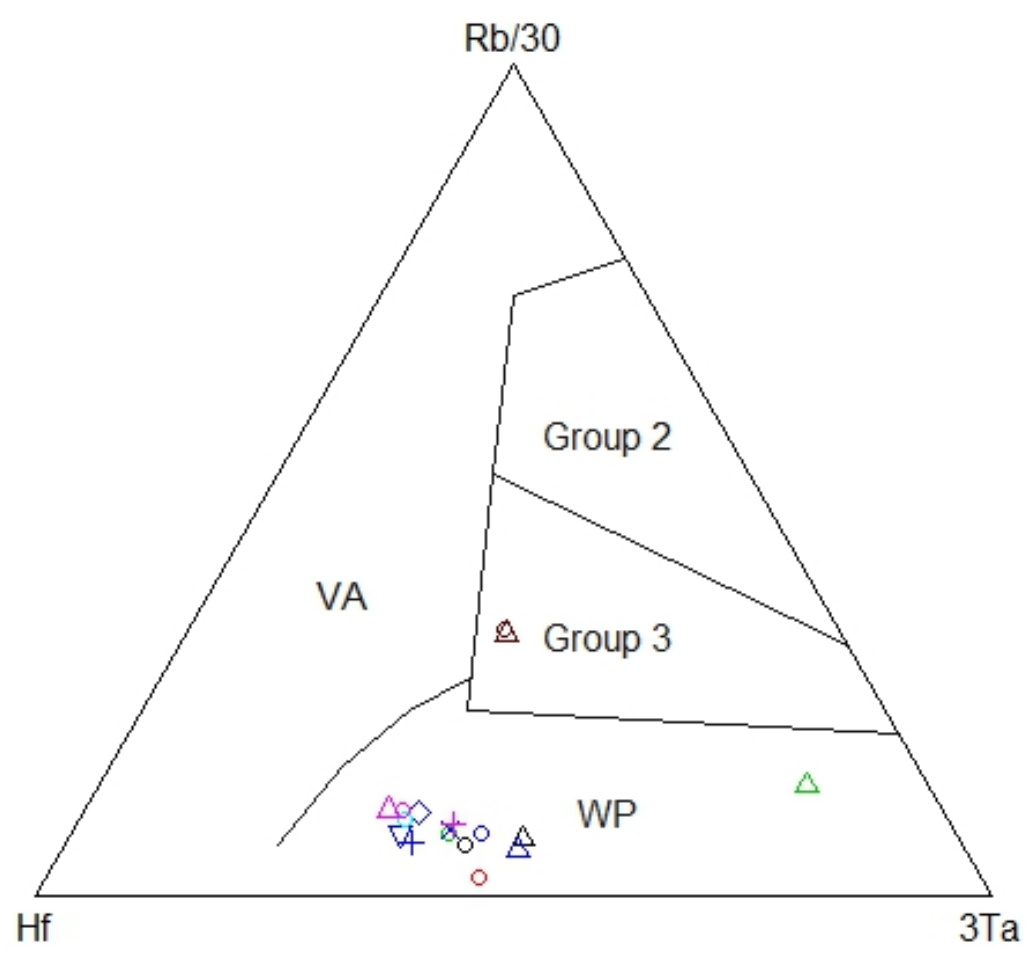

Figure (16): The tectonic setting of sills in the region (Harris et al., 1986)

\subsection{Diagram (Schandl \& Gorton, 2002)}

In these diagrams, which distinguish the rocks in the active continental margin from the rocks in the within plate range, all samples of the sills in the study area are in the within plate (WIP) range. Besides, the S94 and S95 samples of the host rock are in the active continental margin range (Fig. 17). 

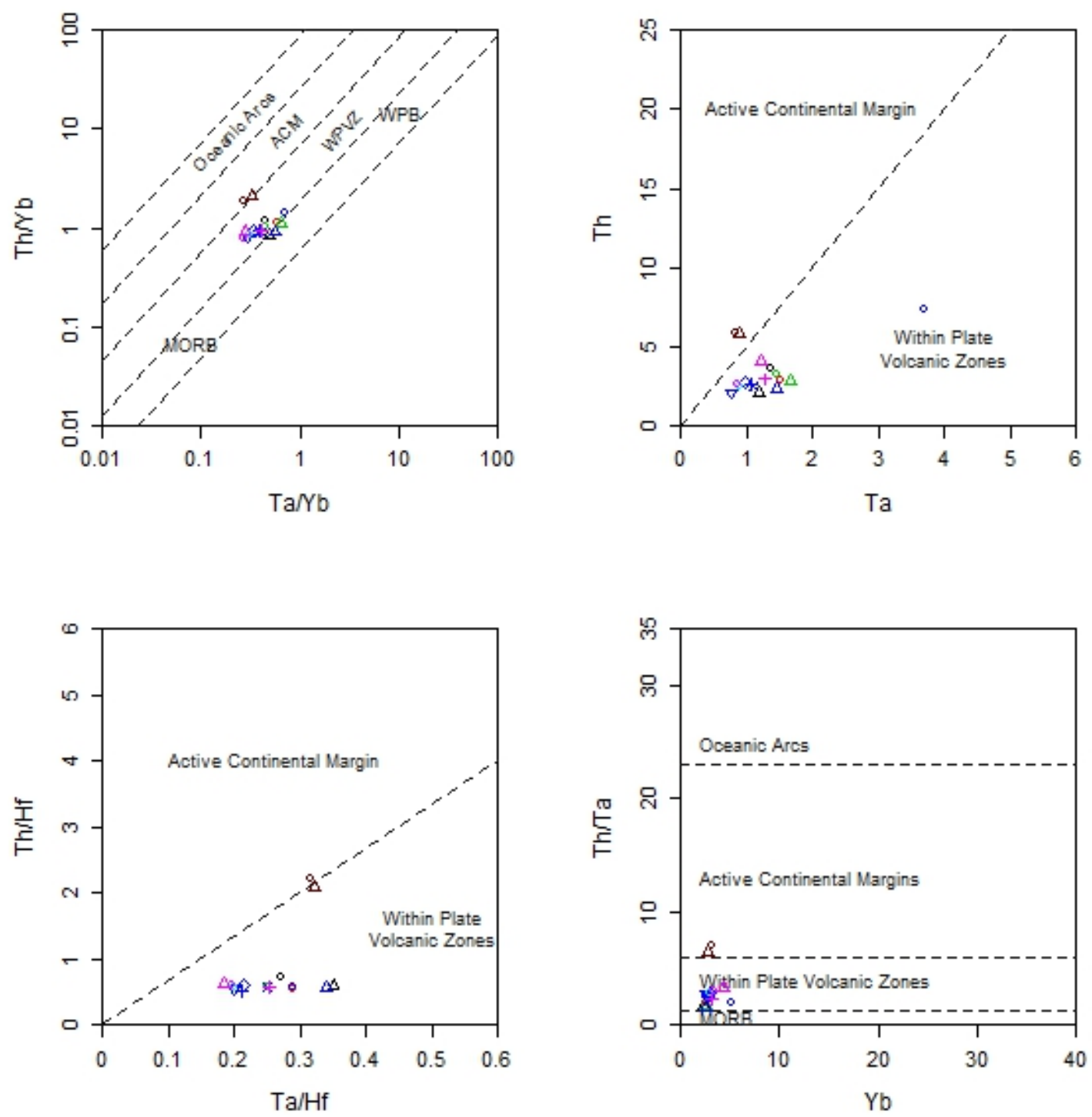

Figure (17): The diagram of sills and the host rock (Schandl, 2002)

\section{CONCLUSION}

The sills in the study area contain various plutonic rocks with basic to neutral chemical compositions. These rocks include gabbro, gabbro diorite, diorite, monzonite, and syenite. In some areas, these rocks have undergone alterations and show traces of the saussuritization phenomenon. There are also two generations of amorphous pyroxenes: The first generation is fully chloritized due to alteration while the second generation is unaltered. Unlike many diorites and monzonites, which typically have hornblendes, neutral rocks such as diorite and monzonite lack any hornblende. This reveals their dry and dehydrated magma. Based on the geochemical studies and the diagrams of the tectonic settings of rocks, the study sills are in the WIN (within plate) range. However, two samples of the host rock are within the range of the active continental margins. 


\section{REFERENCES}

Aghanabati, A. (2004). Geology of Iran. Geological Survey and Mineral Exploration of Iran.

Ashrafi, N., Hasebe, N., Jahangiri, A (2018) Cooling history and exhumation of the Nepheline Syenites, NW Iran: Constraints from Apatite fission track, Iranian Journal of Earth Sciences, 10(2) pp 109-120.

Dabiri, R., Akbari-Mogaddam, M., Ghaffari, M (2018) Geochemical evolution and petrogenesis of the eocene Kashmar granitoid rocks, NE Iran: implications for fractional crystallization and crustal contamination processes, Iranian Journal of Earth Sciences, 10(1) pp 68-77.

Ghadimi, F., Khavari, M (2019) Comparison of original and weighted singularity indexin separation of $\mathrm{Pb}-\mathrm{Zn}$ mineralized zone in the Haft Savaran district, Central Iran, Iranian Journal of Earth Sciences, 11(2) pp 160170.

Gholipour, Sh., Moradi, M. (2011). A geological and structural analysis of Lavasanat region (Northeast of Tehran). The First National Geology Conference in Iran, Shiraz, Islamic Azad University of Shiraz.

Harris et al., (1986). Hf-Rb-Ta diagram. that shows volcanic arc related to subduction zone for Bisheh area samples.

Mullar, D. and Groves, D.I., 1997. Potassic igneous rocks and associated gold copper mineralization. Second edition, Springer Verlog, 242p.

Nazarpour, A (2018) Application of C-A fractal model and exploratory data analysis (EDA) to delineate geochemical anomalies in the: Takab 1:25,000 geochemical sheet, NW Iran, Iranian Journal of Earth Sciences, 10(2) pp 173-180.

Pearce J.A., (1982). Trace element characteristions of lavas from destructive plate boundaries in: Thorpe, R.S. (Eds), Andesites: Otogenic Andesites and Related Rocks. John Wiley and Sons, 252-548.

Pearce, J.A. and Norry M.J., (1979). Petrogenetic implications of Ti, Zr, Y and Nb variations in volcanic rocks. Contrib. Mineral. Petrol. 69, 33-47.

Rabet, M. Aliyani, F. Ghorbani, M. Sepahi, A. A. (2006). Petrography and geochemistry of magma rocks in Lavasan District. The Tenth Conference of the Iranian Geology Society, Tarbiat Modares University.

Safari, S. (2017). A geological report of the northeast of Tehran, Afajeh, Hanzak, Ambaj and Kand villages.

Schandi, E. S. and. Gorton, M. P., (2002). Petrogenesis of Lava from Wainama West, Mount Oku (CVL): Source Characterization and Magma Evolution.

Streekeisen, A.L., (1974). Classification and Plutonic rocks. Recommendations of the IUGS sub commission on the systematic of igneous rocks. Geologische. Runschau. International Zeitschrift for Geologie. Stuttgart. Vol. 63, p.773-785.

Trop, J. Med. Hyg., (1987). Strategies for Surveillance, Prevention and Control of Arbovirus Diseases in Western North America. PP, 77s-86s.

Vahdati, Daneshmand, F. (1995). The 1:100000 quadr angle geological map of east of Tehran. Geological Survey and Mineral Exploration of Iran.

Yazdi, A., Ashja Ardalan, A., Emami, M. H., Dabiri, R., Foudazi, M (2019 -a) Magmatic interactions as recorded in plagioclase phenocrysts of quaternary volcanics in SE Bam (SE Iran), Iranian Journal of Earth Sciences, 11(3) pp 215-225.

Yazdi, A., Shahhosini, E., Dabiri, R., \& Abedzadeh, H. (2019 -b) Magmatic Differentiation Evidences And Source Characteristics Using Mineral Chemistry In The Torud Intrusion (Northern Iran), Revista GeoAraguaia, 9(2): 6-21. 